\title{
What is the Real Impact of Schooling on Age of First Union and Age of First Parenting? New Evidence from Guatemala
}

\author{
Jere R. Behrman, ${ }^{\mathrm{a}}$ Alexis Murphy, ${ }^{\mathrm{b}}$ Agnes Quisumbing, ${ }^{\mathrm{b}}$ Usha Ramakrishnan, ${ }^{\mathrm{c}}$ and Kathyrn \\ Yount ${ }^{\mathrm{C} *}$ \\ ${ }^{a}$ Economics and Demography, University of Pennsylvania, \\ ${ }^{\mathrm{b}}$ Food Consumption and Nutrition Division, International Food Policy Research Institute, \\ ${ }^{\mathrm{c}}$ Global Health, Emory University
}

\begin{abstract}
The ages of first union and of first parenting are of considerable interest, not only because of their implications for individual welfare and well-being over the life cycle, but also because they are strongly associated with fertility patterns that are thought to have important implications for the broader society. But the many positive associations between schooling attainment and ages of first union and first parenting do not mean that increasing education causes increases in ages of first union and first parenting. This study contribute to the literature by investigating the impact of schooling on ages of first union and first parenting using unusually rich data collected over 35 years in Guatemala. It advances beyond the previous literature by: (1) treating schooling as behaviorally-determined, which changes the estimated schooling impacts considerable in a number of cases, tending to result in stronger positive effects of schooling for females and weaker ones for males; (2) including other aspects of individuals' human capital and parental family background, which in some cases changes the estimated impact of schooling attainment a fair amount; and (3) including outcomes, additional to ages of first union and first parenting, such as union partner's human capital and union partner's family' social and economic status, which enriches the understanding of the multiple effects that schooling attainment has on the processes under study.
\end{abstract}

World Bank Policy Research Working Paper 4023, October 2006

The Policy Research Working Paper Series disseminates the findings of work in progress to encourage the exchange of ideas about development issues. An objective of the series is to get the findings out quickly, even if the presentations are less than fully polished. The papers carry the names of the authors and should be cited accordingly. The findings, interpretations, and conclusions expressed in this paper are entirely those of the authors. They do not necessarily represent the view of the World Bank, its Executive Directors, or the countries they represent. Policy Research Working Papers are available online at http://econ.worldbank.org.

*The authors are listed alphabetically. This study was supported by the World Bank World Development Report 2007, NIH/Fogarty grant TW-05598 on "Early Nutrition, Human Capital and Economic Productivity," NSF/Economics grants SES 0136616 and SES 0211404 on "Collaborative Research: Nutritional Investments in Children, Adult Human Capital and Adult Productivities," NIH grant HD046125 on "Education and Health over the Life Course in Guatemala," R01 HD045627-01 grant on "Resource Flows Among Three Generations in Guatemala" NIH/NIA grant P30 AG12836 to PARC at the University of Pennsylvania, the Boettner Center for Pensions and Retirement Security at the University of Pennsylvania, and the Mellon Foundation grant to the Population Studies Center of the University of Pennsylvania. The authors thank their colleagues on the larger project of which this study is a part and Meng Wang for excellent research assistance in the preparation of the data for this paper. The corresponding author is Jere R. Behrman, Economics, McNeil 160, 3718 Locust Walk, University of Pennsylvania, Philadelphia, PA 191046297, USA, jbehrman@econ.upenn.edu. 


\section{Introduction}

The age of first union (marriage or cohabitation) and the age of first parenting are of considerable concern both in academic and in policy communities. Indeed, these are two of the major indicators of transitions from adolescence to adulthood emphasized, for example, in the recently-published $\mathrm{NRC/IOM}$ panel report on transitions to adulthood in developing counties (e.g., NRC/IOM 2005). Both the age of first union and the age of first parenting are of substantial interest not only because of their implications for individual welfare and well-being over the life cycle, but also because they are strongly associated with fertility patterns that are thought to have important implications for the broader society because of externalities (at least given subsidized prices for social services such as schooling and health) as well as for the adolescents and young adults involved.

One major concern in the literature has been that cohabiting and parenting when too young (say, before age 18) limits too much the options of adolescents, particularly women, over their subsequent life cycles and further limits too much the options of their children. While there has been a general tendency for reductions in the proportions of those who are in unions at young ages in most of the developing world, substantial proportions of women still cohabit and begin parenting before they are 18. For this reason there has been substantial interest in the possibilities of delaying forming such unions and initiating parenthood. In a related vein, there is a large literature that presents positive associations between schooling and age of first union and age of first parenting in many societies. Because of these associations, many have been tempted to conclude that one important reason for increasing schooling is to reduce the prevalence of entering into unions and parenthood when young.

But the many positive associations between schooling attainment and ages of first union and first parenting do not mean that increasing schooling would cause increases in ages of first union and first parenting. There are at least three major problems in making such an inference from the available studies.

First, within a dynamic life-cycle framework, schooling, union-formation and initial parenting all reflect behavioural choices that depend on observed and unobserved individual and family background and other characteristics. Some individuals and some families may have unobserved characteristics, such as ability and motivation for schooling that are rewarded in labor markets, that lead to greater investments in schooling and greater delays in union formation and first parenting. If the estimation methods used do not control for the behavioural determinants of schooling, the estimated associations between schooling and the ages of first union and first parenting may be due importantly to the impact of such unobserved factors on all of these behavioural outcomes.

Second, schooling is likely to be only one important factor in union-formation and initial parenting decisions. Other aspects of individuals' human capital (e.g., health, physical attractiveness) and of their parents (e.g., socioeconomic status) are likely to be important determinants of these decisions. Because other dimensions than schooling of individuals' human capital are likely to be determined in part by family background and the other factors that determine schooling, if only schooling is considered as a determinant of ages of first union and first parenting, even if schooling is treated as behaviourally determined, the effect of schooling is likely to be mis-represented (probably overestimated) because in such estimates schooling partially proxies for other human capital and for family background. 
Third, most of the related literature has focused on age(s) of first union and/or first parenting as the outcomes of interest. But there are other outcomes that are determined simultaneously (particularly with the age of first union) that are likely to shape substantially individuals' and their children's subsequent options and welfare. In particular, union partner and union partner family characteristics (e.g., union partner human capital, age gap with union partner, union partner's parental family's social and economic status) are also determined simultaneously with age of first union. ${ }^{1}$ The failure to incorporate such outcomes into the analysis is likely to mean that studies on the impact of schooling on ages of first union and first parenting, even if they are not subject to the problems noted in the first three points above, are likely to result in only a partial understanding of the implications of the processes under study.

In this study we contribute to the literature by investigating the impact of schooling attainment on ages of first union and first parenting using unusually rich data collected over 35 years in a particular developing country context, Guatemala. We advance beyond the previous literature with regard to all three of the limitations in the literature just discussed: (1) We treat schooling as behaviourally determined, (2) we include other aspects of individuals' human capital and parental family background; and (3) we include outcomes additional to ages of first union and first parenting, such as union partner's human capital and union partner's family's physical and human assets. Throughout all of this analysis, as in almost all of the previous literature, we consider gender differences because of the considerable emphasis in the literature on young ages of first union and first parenting being experienced particularly by women and being particularly detrimental to women.

We organize this study by first presenting a brief overview of previous relevant literature on patterns in the ages of first unions and first parenthood and some associations and determinants throughout the developing world (Section 2), then presenting a conceptual framework (Section 3), then presenting the data (Section 4), then presenting our alternative estimates for each of a number of outcomes (Section 5), and finally concluding (Section 6).

\section{Overview of Patterns in Ages of First Union and of First Parenting in Developing Countries}

The recent NRC/IOM (2005) panel report on transitions to adulthood referred to above has summarized the state of knowledge on patterns in and determinants of ages of first union and first parenting. The major points that this report emphasizes are:

\section{Transition into first union:}

- Compared with previous generations, smaller proportions of young women and men are in unions in most regions. Men still form unions at older ages than women. While only one-

\footnotetext{
${ }^{1}$ There is a large literature on assortative mating on schooling (a prominent example is Mare 1991), but for the most part in this literature there is no attention to behavioral determinants of schooling and the possibilities of important unobserved variable bias. An early exception is Boulier and Rosenzweig (1984), but they identify the schooling impact by the assumption that parental income/occupation only affects schooling directly, not age of marriage or the marriage match. Another exception is Behrman and Rozenzweig (2002) who find that estimated assortative mating on schooling attainment falls considerably with control for unobserved endowments (through using data on identical twins to control for shared endowments) that might affect both schooling and union outcomes
} 
third of men in the developing world are in unions by ages 20-24, nearly two-thirds of women in this age group are.

- Entry into unions, particularly marriage, continues to be (as in the past) strongly associated with entry into parenthood, suggesting that the timing of marriage is typically seen by the couple themselves and/or by their families as coinciding with readiness for parenthood. With delays in the age of marriage, this gap in timing between the age at marriage and the age at first birth has narrowed, falling from 22 to 16 months on average over the past 20 years among the overwhelming majority of women whose first birth occurs after marriage.

- The minimum legal age of marriage for both men and women has risen in many countries in the last decade and women are less likely to be married during their teenage years than previously. However, child marriage, defined as marriage prior to age 18 , is still widespread and viewed by some as a major violation of human rights. Based on survey data representing 60 percent of the population of the developing world, 38 percent of young women ages 20 to 24 married before age 18 (down from 52 percent twenty years ago), with the highest rates of child marriage currently occurring in West Africa and South Asia. Young women who marry as minors are more likely to come from poor households and rural areas and to have relatively few grades of schooling attainment.

- The age gap between spouses - often thought of as a measure of the degree of equality in marriage - appears to be narrowing, especially in Sub-Saharan Africa and South and Southeast Asia. There is also some evidence of growing agency on the part of young women with regard to choices of marriage partnesr, suggesting that the nature of marriage itself is changing.

\section{Transition to first parenthood:}

- Over 90 percent of first births occur within marriage, a percentage that has changed only minimally over the past twenty years. With rising ages of marriage, the ages of parenthood are also rising, allowing young people more time to prepare for this important adult role and providing an increasing number of young women with the opportunity to participate in the labor force prior to becoming a parent. Due to a lack of data and research, little is known about the timing and experience of first parenthood for young men.

- Rates of early childbearing remain high in many parts of the developing world because of high rates of early marriage, noted above. Based on survey data representing 60 percent of the population of the developing world, 23 percent of young people ages 20-24 gave birth before the age of 18 (down from 30 percent 20 years ago). The pace of decline in early parenthood has been most rapid in those regions where rates of early marriage and parenthood were historically high.

- Associated with these declines in early marriage and early childbearing, there has been a slight rise in the percentage of births to young women that are premarital. The level of premarital childbearing varies substantially across regions from 14 percent having a premarital birth by the age of 20 in East and Southern Africa to less than 1 percent in Asia and the Middle East. While East and Southern Africa and South America have seen recent 
small increases in the rates of premarital childbearing, the rates in other regions appear very low.

- Although there is plentiful evidence that early childbearing is correlated with various negative outcomes, rigorous research confirming a causal role for age at birth in producing these outcomes does not exist. Major global changes such as increasing school enrollment during late adolescence, rising rates of labor force participation among young women, and rising HIV/AIDS prevalence among young women in Africa are likely to have important implications for the transition to parenthood, but little is yet known about the implications of these trends for first parenthood.

\section{Conceptual Framework}

Our conceptual framework considers the life cycle to have a series of stages. One of those stages is early adolescence, during which for the society that we consider, most individuals complete their formal schooling. For our sample, for example, two-thirds completed their formal schooling by age 13 and over four-fifths by age 15. At the end of the early adolescence stage, we posit that individuals have a vector of human capital stocks $\left(\mathrm{K}_{\mathrm{a}}\right)$ that include schooling and health. They also are from a parental family that has a vector of characteristics $\left(F_{a}\right)$ such as parental schooling attainment and parental SES. During the next life-cycle stage individuals form unions and initiate parenting, as well as undertake other transitions. ${ }^{2}$ These unions are both between individuals and between families, so both individual and family characteristics may affect the timing and the nature of these unions. Let $\mathrm{Y}$ be a vector of outcomes that relate to forming their first union and their first parenting - e.g., age of first union, whether first union was a marriage, ${ }^{3}$ age of first parenting, age gap between first union and first parenting, whether young first union (under $18 \mathrm{y}$ of age), whether young first parenting (under $18 \mathrm{y}$ of age), partner characteristics (age gap, schooling attainment, health) and partner's parental family characteristics (parental schooling attainment, land holdings). The basic interest of this study is to estimate how Y depends on schooling, which is one of the components of $\mathrm{K}_{\mathrm{a}}$. We posit that there is a linear approximation to what determines $\mathrm{Y}$ given the human capital stocks $\left(\mathrm{K}_{\mathrm{a}}\right)$ and parental family characteristics $\left(\mathrm{F}_{\mathrm{a}}\right)$ at the end of early adolescence, unobserved inherent endowments $\left(\mathrm{E}_{0}\right)$ such as innate ability and charm and a vector of stochastic disturbance terms, one each for each different outcome (U):

(1) $\mathrm{Y}=\mathrm{a}_{0}+\mathrm{a}_{1} \mathrm{~K}_{\mathrm{a}}+\mathrm{a}_{2} \mathrm{~F}_{\mathrm{a}}+\mathrm{a}_{3} \mathrm{E}_{0}+\mathrm{U}$,

where the $a_{i}$ are matrices of coefficients to be estimated and where all the coefficients may differ by gender. .

The questions that are posed in the introduction pertain to obtaining good (consistent) estimates of the coefficients of schooling in relation (1), which is one of the components of $\mathrm{K}_{\mathrm{a}}$, for each of the components in Y. But estimation of relation (1) is a challenge because the human capital stocks at the end of the early-adolescent stage $\left(\mathrm{K}_{\mathrm{a}}\right)$ all reflect previous behavioral choices so OLS, simple probit or similar estimates of relation (1) are likely be inconsistent due to endogeneity. We assume

\footnotetext{
${ }^{2}$ Only $4 \%$ of our sample initiated their first union prior to completing formal schooling. That is not a large enough subsample to permit treating them differently in the analysis, so we combine this $4 \%$ with the other $96 \%$ in the analysis even though they formed unions prior to completing formal schooling.

${ }^{3}$ At the time of the 2002-4 survey (see Section 4.1 below), the majority of those in unions were formally married, but a substantial minority (44\%) of those who were in unions were not married.
} 
that individuals and their parental families make investments in each life-cycle stage within a dynamic, reduced-form demand context, given initial conditions (including parental family background $\mathrm{F}_{0}$, initial community prices and policies $\mathrm{C}_{0}$, genetic and other endowments $\mathrm{E}_{0}$, and individual characteristics $\mathrm{I}_{0}$ such as sex and age) and changes that occurred over time such as those in markets, policies and other conditions $\Delta \mathrm{C}$ (conditional on the individual's birth year and subsequent age):

(2) $\mathrm{K}_{\mathrm{a}}=\mathrm{K}\left(\mathrm{F}_{0}, \mathrm{C}_{0}, \mathrm{E}_{0}, \mathrm{I}_{0}, \Delta \mathrm{C}, \mathrm{V}\right)$, where $\Delta$ refers to observed changes or shocks from the initial conditions to the end of the early-adolescent life-cycle stage, and $\mathrm{V}$ refers to unobserved idiosyncratic influences.

This expression encapsulates the results of many decisions that parents, and then increasingly the children themselves, make over the children's life cycle, given initial conditions and time-varying factors outside of the control of the family. The elements in relation (2) are in general vectors of opportunities and constraints to which the family responds. One example is the genetic endowments $\left(\mathrm{E}_{0}\right)$, a vector that includes innate "ability" endowments related to learning and "physical" endowments related to physical growth. ${ }^{4}$

Consideration of relations (1) and (2) illustrates the three important aspects of the problems of estimates in the literature of relation (1) that are mentioned in the introduction. First, all of the human capital stocks at the end of the pre-adolescent stage are determined in part by genetic and other endowments $\left(\mathrm{E}_{0}\right)$ that also are posited to have direct effects on the outcomes of interest in relation (1). This means that to obtain consistent estimates of the impacts of schooling (or of other human capital stocks) on age of first union formation and age of first parenting and other outcomes of interest, some combination of data and estimation method must be used to avoid the bias that otherwise would result from correlations between the capital stocks and the expanded compound error term in relation (1) that includes unobserved genetic and other endowments $\left(\mathrm{E}_{0}\right)$ in addition to the idiosyncratic error $(\mathrm{U})$. This problem can be addressed in principle by random assignment of human capital stocks, by direct control for genetic and other endowments $\left(\mathrm{E}_{0}\right)$ or by instrumental variable (IV) estimates in which each component of the capital stocks in relation (1) is replaced by its predicted value from relation (2), which is not correlated with the unobserved $\mathrm{E}_{0}$ and therefore not correlated with the compound disturbance in relation (1). In the present (and almost all) data sets, only the third of these is an option. ${ }^{5}$ However in the literature on the impact of schooling on formation of first union and initiating parenting in developing countries, there are to our knowledge no satisfactory efforts to deal with the fact that schooling is determined by behavioral choices. We do so in this study using IV estimators. Second, all of the human capital stocks are determined in part by the same initial conditions $\left(\mathrm{F}_{0}, \mathrm{C}_{0}, \mathrm{E}_{0}, \mathrm{I}_{0}\right)$ and some common observed community changes $\Delta \mathrm{C}$ and unobserved influences $\mathrm{V}$. This means that the capital stocks are likely to be correlated, with

\footnotetext{
${ }^{4}$ These various endowments may be significantly correlated but they need not be positively correlated. A recent study for the United States, for example, finds that the endowments related to schooling and earnings on one hand and those related to physical health on the other, are negatively correlated (Behrman and Rosenzweig 2004). If that were the case in this study, the failure to control for genetic endowments could result in an overestimate of the effect of schooling on the quality of the union partner as measured, for example by the partner's adult cognitive skills, but an underestimate of the effect of an indicator of physical development (such as height-for-age) on those same skills.

${ }^{5}$ Within-sibling estimates could be used to control for the average family genetic endowments, but previous studies suggest that the individual-specific deviations from those family averages have important impact on human capital investments (Behrman, Rosenzweig and Taubman 1994, 1996). If there are gender differences in the coefficients, moreover, within-brother and within-sibling estimates would be required to control for family endowments, and our data set does not have sufficient numbers of brother and sister pairs to permit such estimates.
} 
the result that estimates that do not control for all of these capital stocks and for the family background characteristics in the early-adolescent stage (that also are likely to be correlated because of the role of family background in determining the human capital investments) — as in most of the literature that only includes schooling - are likely to be subject to omitted variable bias because of the failure to control for the other components of human capital and for parental background characteristics. We investigate how important this problem is by comparing alternative specifications that have multiple measures of different components of human capital plus family background with one in only schooling is included. Third, most of the focus in the literature is related to a few components of Y, primarily age of first union and age of first parenting. We investigate these outcomes, but also consider a number of other outcomes noted above and elaborated on in Section 4.2 -- whether age gap between first union and first parenting, whether young first union (under $18 \mathrm{y}$ of age), whether young first parenting (under $18 \mathrm{y}$ of age), partner characteristics (age gap, schooling attainment, health) and partner's parental family characteristics (parental schooling attainment, land holding). This permits a much richer assessment of the impact of schooling on the initial union formation and parenting.

\section{Section 4. Data}

The data demands are considerable for estimating the relations posited in Section 3. We utilize an unusually rich longitudinal data set collected over a 35-year period with union and parenting histories and alternative measures of human capital (e.g., school attainment, height to represent long-run nutritional and health status), family background and shocks from an experimental intervention and market and policy changes. We first provide a brief general description of the data $^{6}$ and then focus on the particular variables that we use in the analysis.

\section{Section 4.1 General Description of the Data}

In the early and mid-1960s, protein deficiency was seen as the single most important nutritional problem facing the poor in developing countries and there was considerable interest in the possibility that this deficiency affected children's ability to learn. The Institute of Nutrition for Central America and Panama (INCAP), based in Guatemala, became the locus of a series of preliminary studies on this subject in the latter half of the 1960s (see Habicht and Martorell 1992, Martorell, Habicht and Rivera 1995 and, especially, Read and Habicht 1992). These informed the development of a larger scale supplementation trial that began in 1969.

The data used in this study are from that larger supplementation trial, collected for individuals who were 0-7 y old during 1969-77 in four villages in Eastern Guatemala. Three villages - San Juan, Conacaste and Santo Domingo - are located in mountainous areas with shallow soils, while the agricultural potential of Espíritu Santo, located in a river valley, is somewhat higher. All four villages are located relatively close to the Atlantic Highway, connecting Guatemala City to Guatemala's Caribbean coast—from 36km to $102 \mathrm{~km}$ from Guatemala City. From January 1969 to February 1977 INCAP implemented a nutritional supplementation trial in these four villages, together with data collection on child growth and development. ${ }^{7}$ The data collection focused on all

\footnotetext{
${ }^{6}$ For more extensive discussion of the data, see Grajeda et al. (2005), Hoddinott, Behrman and Martorell (2005), Maluccio et al. (2005b), Martorell et al. (2005), Quisumbing et al. (2005), Ramakrishna et al. (2005) and Stein et al. (2005).

7 The intervention began in the larger villages, Santo Domingo and Conacaste, in February 1969, and in the smaller villages, Espíritu Santo and San Juan, in May 1969.
} 
village children aged seven years or less and all pregnant and lactating women. Cohorts of newborns were included until September 1977. Data collection for individual children ceased when they reached seven years of age. The birth years of children included in the 1969-77 longitudinal data collection thus range from 1962 to 1977, so when the intervention ended, their ages ranged from 0 to 15 years. ${ }^{8}$ Therefore the length and timing of exposure to the nutritional interventions (described below) for particular children depended on their respective birth dates. For example, only children born after mid-1968 and before October 1974 were exposed to the nutritional intervention for all of the time they were from six to 36 months of age, which often is posited to be a critical time period for child growth in the nutrition literature (see Maluccio et al. 2005, Martorell, Habicht and Rivera 1995 and Martorell et al. 2005 and the references therein).

The principal hypothesis underlying the intervention was that improved pre-school nutrition accelerates physical growth and mental development. To test this hypothesis, 300 villages were screened to identify those of appropriate size, compactness (so as to facilitate access to feeding stations, health centers and psychological testing sites, see below), ethnicity, diet, educational levels, demographic characteristics, nutritional status and degree of physical isolation. From this screening, village pairs similar in these characteristics were determined: Conacaste and Santo Domingo (relatively populous villages) and San Juan and Espíritu Santo (relatively less populous villages).

Two villages, Conacaste and San Juan, were randomly assigned to receive a high protein-energy drink, Atole, as a dietary supplement. Atole contained Incaparina (a vegetable protein mixture developed by INCAP), dry skim milk, and sugar and had $163 \mathrm{kcal}$ and $11.5 \mathrm{~g}$ of protein per $180 \mathrm{ml}$ cup. This design reflected the prevailing view of the 1960 's that protein was the critically limiting nutrient in most developing countries. Atole, the Guatemalan name for hot maize gruel, was served hot; it was pale gray-green and slightly gritty, but with a sweet taste.

In designing the data collection, there was considerable concern that the social stimulation associated with attending feeding centers - such as the observation of children's nutritional status, the monitoring of their intakes of Atole and so on-also might affect child nutritional outcomes, thus confounding efforts to understand the impact of the supplement. To address this concern, in the remaining villages, Santo Domingo and Espíritu Santo, an alternative drink, Fresco, was provided. Fresco was a cool, clear-colored, fruit-flavored drink. It contained no protein and only sufficient sugar and flavoring agents for palatability. It contained fewer calories per cup (59 $\mathrm{kcal} / 180 \mathrm{ml}$ ) than Atole. Several micronutrients were added to the Atole and Fresco in amounts that achieved equal concentrations per unit volume. This was done to sharpen the contrast between the drinks to protein; the energy content differed, of course, but this was not recognized to be of importance at the time.

The nutritional supplements (i.e., Atole or Fresco) were distributed in supplementation centers and were available daily, on a voluntary basis, to all members of the community during times that were convenient to mothers and children but that did not interfere with usual meal times. For this study, with the differential "intent to treat" exposure to these nutritional supplements as first-stage instruments to estimate relation (2), a critical question is to what extent the intervention design

\footnotetext{
${ }^{8}$ Though the number of villages is small, the number of village-birth-year cohorts is 64 , which provides a reasonable number of clusters for estimation of standard errors that account for clustering. Maluccio et al. (2005a) and Behrman et al. (2005) provide such estimates and report that they do not differ much from estimates with robust standard errors as are used in the present study.
} 
resulted in differences in access to calories, proteins and other nutrients. In addressing this question, we can exploit the intensive nature of the survey and observational work associated with the intervention. Averaging over all children in the Atole villages (i.e., both those that consumed any supplement and those who never consumed any), children 0-12 months consumed approximately 40-60 kcal per day, children 12-24 months consumed 60-100 kcal daily and children 24-36 months consumed 100-120 kcal per day as supplement (Schroeder, Kaplowitz and Martorell, 1992, Figure 4). Children in the Fresco villages, in contrast, consumed virtually no Fresco between the ages of 0-24 months (averaging at most $20 \mathrm{kcal}$ per day) with this figure rising to approximately 30 kcal daily by age 36 months (Schroeder, Kaplowitz and Martorell, 1992, Figure 4). ${ }^{9}$ Micronutrient intakes from the supplements were also larger for Atole than Fresco villages; also, the Atole contributed significant amounts of high-quality protein, while the Fresco contributed none.

A program of primary medical care was provided free of charge throughout the period of data collection. Periodic preventive health services, such as immunization and deworming campaigns, were conducted in all villages. This population has been studied intensively in the years since the original data collection, with particular emphasis on the impact of the nutritional intervention (Martorell et al. 2005 gives references to many of these studies).

A multidisciplinary team of investigators, including the authors of this paper, undertook follow-up data collection in 2002-4 on all participants in the 1969-77 data collection (i.e., subjects born between 1962 and 1977). In 2002-4, sample members ranged from 25 to 42 years of age. Figure 1 (based on Grajeda et al. 2005, Figure 1) shows what happened to the 2393 individuals 0-15 years old in the original 1969-77 data collection by the time of our 2002-4 data collection: 1856 (77\%) were alive and known to be living in Guatemala ( $11 \%$ had died, $8 \%$ had migrated abroad, $4 \%$ were not traceable). Of these 1856, 1113 lived in the original villages, 154 lived in nearby villages, 419 lived in or near to Guatemala City, and 170 lived elsewhere in Guatemala. For the 1856 traceable sample members living in Guatemala, $1054(58 \%)$ finished the complete battery of applicable interviews and measurements and 1570 (85\%) completed at least one interview during the 2002-4 data collection. For two-thirds of the $286(15 \%)$ who completed no interviews, while we learned they were alive and living in Guatemala, we were unable to obtain current addresses and therefore could not make contact. The refusal rates for at least partial participation among those whom we were able to contact were low, around 5\%. (For further details, see Grajeda et al. 2005.)

[Figure 1 about here]

\section{Section 4.2 Central Variables for the Analysis}

Table 1 presents means, standard deviations (SD) and sample sizes (n) by gender for the central variables that appear in relation (1).

[Table 1 about here]

Dependent Variables -- Union-Formation and Parenting-Related Outcomes (Y): We consider four groups of outcomes in our estimates in Section 5.

1) Ever in a union and whether young (under 18y) at initiation of first union and first parenting: Most women (88\%) and almost as high a proportion of men $(83 \%)$ have had at least one

\footnotetext{
${ }^{9}$ In contrast, their mothers consumed considerable quantities.
} 
union. Among women over a quarter (28\%) were under 18 y at their first union, and over a fifth $(22 \%)$ were under $18 \mathrm{y}$ when they first became a parent. For men, the percentages of those under $18 \mathrm{y}$ at their first union $(6 \%)$ and at first parenting (4\%) are much lower.

2) Age at first union and first parenting: The mean age of first union (for those who have had a union) for males is $22.1 \mathrm{y}$ and the mean age of first parenting (for those who have had a child) is $23.2 \mathrm{y}$, with a mean gap of $1.3 \mathrm{y}$. For females the mean ages are lower - respectively, $19.8 \mathrm{y}$ and $20.3 \mathrm{y}-$ and the mean gap of $0.6 \mathrm{y}$ is smaller.

3) Age gap with partner and partner characteristics: Males tend to be older (by an average of about 3y), have greater schooling (by an average of 0.4-0.8 grades), bring substantially greater assets to the marriage (on average, over five times as much though there is substantial variance), ${ }^{10}$ are taller (by an average of about $12 \mathrm{~cm}$ ), and are likely to be less overweight ${ }^{11}$ than their female partners.

4) Partner's parental family ("in-laws”) characteristics: Males on average form unions with females with larger land holdings (though, again, there is substantial variance) and with about the same or somewhat less schooled parents.

\section{Explanatory Variables:}

1) Early Adolescent Life-Cycle Stage Capital Stocks $\left(K_{a}\right)$ : The schooling attainment of males (5.3 grades) exceeds the schooling attainment on average of females (4.5 grades). ${ }^{12}$ In addition to schooling attainment, we consider an indicator of long-run nutritional and health status, height; males average $162.8 \mathrm{~cm}$ and females average $150.5 \mathrm{~cm}$.

2) Family Background in Early-Adolescent Lifecycle Stage $\left(F_{a}\right)$ : We represent family background by mother's and father's schooling attainments and a constructed socioeconomic status score that is the first principal component of both the assets owned and the housing characteristics of the parental household in 1975 (Maluccio, Murphy and Yount 2005). ${ }^{13}$ On average these characteristics do not differ much between males and females.

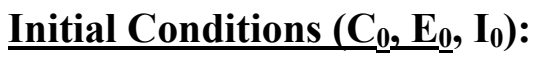

Community characteristics in childhood $\left(\mathrm{C}_{0}\right)$ : Communities differ significantly in their learning environments, in part because of different experiences of prior generations regarding schooling and occupational structure (Bergeron 1992; Maluccio, et al. 2005b). We control for the permanent, or fixed, dimensions of these differences by including village fixed effects in the first stage regressions.

\footnotetext{
${ }^{10}$ Data on physical and financial assets bought to marriage are fairly rare, but some previous studies suggest that these assets may have important impacts on intrahousehold allocations (e.g., Quisumbing and Maluccion 2003, Quisumbing and Hallman 2005).

${ }^{11}$ BMIs between 25 and 30 generally are characterized as "overweight" and BMIs 30 and above are characterized as "obese."

12 By "schooling attainment" in this study we mean the completed grades of formal schooling, not including training courses that were sometimes taken by sample members, often after they had completed formal schooling for a number of years and were in their twenties.

${ }^{13}$ In our estimates below we include dummy variables for missing values if these variables are missing but the other relevant variables are not.
} 
Genetic endowments $\left(\mathrm{E}_{0}\right)$ : We do not have direct observations on genetic endowments beyond the sex of individuals, for which we control in our estimates. However, we are not able to identify confidently the extent to which this control reflects genetic differences or cultural and marketdetermined gender differences.

Observed individual characteristics $\left(\mathrm{I}_{0}\right)$ : Apart from sex of the individual, we include year of birth.

\section{Observed Shocks and Events $(\Delta \mathrm{C})$ :}

Natural, market or policy events $(\Delta \mathrm{C})$ : We construct variables at the community level that relate as closely as possible to the timing of key decisions in an individual's development through early adolescence. For example, using information reported in earlier work about infrastructure, markets and services in the villages (Pivaral 1972; Bergeron 1992), complemented with a retrospective study in 2002 (Estudio 1360, 2002), we construct variables that include indicators or policies (e.g., the nature of the water supply when the individual was two and seven years old, the presence of a Ministry of Health post in the community when the individual was two and seven years old, the availability of a permanent structure primary school when the individual was seven and 15 years of age, student/teachers ratios when the individual was seven and 15 years of age, number of grades offered in local school when individual was seven years old) and local market conditions (e.g., yuquilla bust, vegetable boom, cement factory jobs, good road access all when the individual was 15 years of age). Thus, while reflecting community level characteristics, these variables vary by single-year age cohorts within each village, as well as across villages. Since these measures more closely relate the availability and longevity of water, health posts, schools, markets and transportation to the periods in an individual's life when critical decisions (e.g., attending school, working in the labor market) were being made, it is an improvement over the more typical approach of including indicators about such factors in a given year for a population with different ages at that point.

Experimental nutritional shocks $(\Delta \mathrm{C})$ : The set of observed shocks that we consider relate to the nutritional interventions underlying the original study (see Section 4.1). We construct two types of measures, based on the date of birth of each individual and the dates of operation of the intervention. For each individual, we calculate whether s/he was exposed to either intervention for the majority of days for 36 months subsequent to birth. We interpret these as a set of cohort controls. The potential exposure to the Atole intervention is then calculated by multiplying the cohort measure by an indicator of whether or not the child lived in one of the two Atole villages. We include these two measures separately.

\section{Results}

We consider estimates of the impact of schooling attainment for each of the four groups of outcomes considered at the start of Section 4.2 and for which the sample characteristics are summarized in Table 1. For each outcome we consider estimates of the impact of schooling attainment (1) in a very simple specification (i.e., only including schooling attainment without treating it as behaviorally-determined), (2) with only schooling attainment but with schooling attainment treated as behaviorally-determined using IV estimates, (3) with both schooling attainment and height both treated as behaviorally-determined using IV estimates, and (4) with both schooling attainment and height both treated as behaviorally-determined using IV estimates plus 
parental schooling and the household wealth index. For all estimates we consider females and males separately. For all estimates we use Huber (1967)-White (1980) robust standard errors to test levels of significance.

1) Ever in a union and whether young (under 18 y) at initiation of first union and first parenting (Table 2): Probit estimates do not yield significant effects of schooling attainment on whether females or males have ever been in a union as of the time of the 2002-4 survey. When schooling is treated as behaviorally-determined with IV probits, whether or not there is control for height, for females greater schooling attainment is estimated to reduce the probability of ever being married significantly ${ }^{14}$ and with point estimates about six times as large as in the simple probits. This pattern suggests that there are unobserved factors (e.g. preferences for independence) that directly reduce the probability of ever being in a union and that are positively correlated with schooling attainment, so that when these factors are ignored in the probit estimates, the estimated impact of schooling attainment is greater algebraically (i.e., less negative) than if there is control for these factors.

Probit estimates suggest significant negative effects of schooling attainment on whether young (under 18 y) at initiation of first union for both females and males, but with the estimated associations about three times as large for females as for males. If schooling attainment is treated as behaviorally-determined with IV estimates, there is no evidence of a significant impact for males. For females, in contrast, there still is a significantly negative impact for the alternative IV probit estimates that suggests an effect about $50 \%$ bigger in absolute magnitude than in the simple probits. This suggests that for females the unobserved factors that reduce the probability of ever having been in a union also reduce the probability of being in a union when young and - if not controlled in the estimates - lead to underestimates of the impact of schooling attainment on initiating the first union when under $18 \mathrm{y}$ for females.

None of the estimates suggest a significant impact of schooling attainment on whether young (under 18 y) at time of first parenting for males. For females, however, there is a pattern of significant negative estimates similar to those for whether young at initiation of first union - with the IV probit estimates a third to a half bigger in absolute magnitude than the simple probit estimates (though in this case somewhat more of a suggestion that schooling attainment is partly proxying for parental characteristics in the first three estimates if the correct specification is that parental characteristics have direct effects on the outcome as posited in the fourth set of estimates).

2) Age at first union and first parenting (Table 3): For males, the censored OLS regression estimates suggest that the mean age of first union for males increases by 0.17 years for every additional grade of schooling attainment. But when schooling is treated as behaviorally determined, the estimates for males are not significant. Therefore it appears that there is some unobserved variable that affects positively both schooling attainment and age of marriage for males (e.g., innate ability, ambition, materialism) that, if not controlled in the estimates, results in the appearance of a significant impact of schooling attainment on age of first union but that is not significant once schooling is treated as behaviorally-determined. For females, in contrast, the censored OLS estimates suggest a much larger (than for males) significantly positive impact of 0.44 years for every additional grade of schooling attainment that persists in the IV estimates - and perhaps even increases if there is control for height. Height, however, is significantly non-zero only at the 0.10 level and only in the third set of estimates. In this case it is negative, which suggests that taller

${ }^{14}$ We use "significantly" to refer to the 0.05 level of significance unless otherwise noted. 
females tend to form their first union about when they are about 0.30 years older for every additional $\mathrm{cm}$ of height.

For males none of the estimates suggest that the mean age of first parenting is affected significantly by schooling attainment. For females, in contrast, the censored OLS regression suggests that for every additional grade of schooling attainment first parenting is delayed by about half a year, and the IV estimates suggest that, if anything, the effects are from $30 \%$ to $67 \%$ greater.

For neither females nor males do any of the alternative estimates suggest a significant impact of schooling attainment on the gap between the age of first union and the age of first parenting (Appendix Table A).

3) Age gap with partner and partner characteristics (Table 4): OLS estimates indicate no significant associations for schooling attainment with the age gap with partner for either females or males. For males, however, the IV estimates suggest that increased own human capital reduces the age gaps. The IV estimates with only schooling attainment suggest a decline of about 0.4 years in the age gap for every additional grade of schooling attainment. But once height is included, the IV estimates suggest that schooling attainment is not significant but that long-run nutritional and health status is, with a decline of 0.4 to 0.5 years in the age gap for every additional $\mathrm{cm}$ of height.

As in almost all, if not all, data sets, the OLS estimates indicate strong associations between own schooling attainment and partner's schooling attainment, with an addition 0.5 grade for every additional grade of male's own schooling attainment and an additional 0.6 grade for every additional grade of female's own schooling attainment. The IV estimates suggest significant positive effects that, if any thing, may be a little larger (i.e., the point estimates are 15 to $26 \%$ higher for males and 19 to $36 \%$ higher for females). The contrast is sharp with the estimates for the United States in Behrman and Rosenzweig (2002, Table 2) where the schooling coefficient estimates decline by $42-63 \%$ with control for endowments using identical twins data due to what the authors interpret to be positive assortative mating on unobserved characteristics such as innate ability and preferences. The estimates in Table 4 suggest, if anything, that the OLS estimates understate the extent of assoratative mating on schooling attainment because of some combination of negative assortative mating on unobservables (as suggested, for example, by Becker 1991 due to gender specialization in market versus nonmarket activities) and of random measurement error.

Schooling attainment has no significant coefficient estimates with partner's assets bought into the union for any for the alternative estimates for either females or males. Thus there does not seem to be substitution between these physical assets and human assets in the marriage markets under study.

The OLS estimates suggest significant positive associations of own schooling attainment with partner's height for both females and males, but not with partner's BMI. But the IV estimates suggest different stories. For males the IV estimates suggest no significant effects of own schooling attainment on partner's anthropometrics (though there is a weak suggestion of assortative mating on height in the fourth set of estimates). For females, the IV estimates for partner's height with only schooling suggest a significant negative impact, but the parallel coefficient estimates are not significantly nonzero for the more extensive specifications (3) and (4). The IV estimates for female partner's BMI, however, indicate a more robust negative impact of greater own schooling attainment on partner's BMI - suggesting that for every additional grade of schooling for females, the BMI of their partners is about 0.4 to 0.5 less (which is about a tenth of the sample SD in Table $1)$. 
4) Partner's parental family ("in-laws") characteristics (Table 5): There do not seem to be robust effects of own schooling attainment on inlaws' land holdings, though the IV estimates suggest that more-schooled males may marry into families with less land (but only in the fourth specification is the coefficient estimate significantly nonzero).

In contrast, the OLS estimates indicate significant positive associations between own schooling and parent-inlaw schooling attainments, that become bigger for the IV estimates that control for the behavioral determination of own schooling attainment and that generally tend to be, if anything, bigger for females than for males. The IV estimates for female's father-in-law's schooling attainment, in fact, are so large - suggesting that for every additional grade of own schooling female's father's-in-law have 0.7 to 0.8 grades of schooling - as to raise questions of plausibility. Nevertheless, the estimates for parent-inlaw schooling attainment as a group suggest that individuals with more schooling attainment marry into families with greater schooling attainment, possibly more so than the OLS associations alone suggest.

\section{Conclusions}

The age of first union and the age of first parenting are of considerable concern both in the academic and in the policy areas, not only because of their implications for individual welfare and well-being over the life cycle, but also because they are strongly associated with fertility patterns that are thought to have important implications for the broader society as well as for the adolescents and young adults involved. But the many positive associations between schooling attainment and ages of first union and first parenting in the previous literature do not mean that increasing education causes increases in ages of first union and first parenting. There are at least three major problems in making such an inference from previous studies, as discussed in the introduction. In this study we contribute to the literature by investigating the impact of schooling attainment on ages of first union and first parenting using unusually rich data collected over 35 years in Guatemala. We advance beyond the previous literature with regard to all three of these limitations in the literature: (1) We treat schooling as behaviorally-determined, (2) we include other aspects of individuals' human capital and parental family background; and (3) we include outcomes, additional to ages of first union and first parenting, such as union partner's human capital and union partner's family' social and economic status. We summarize our results with respect to each of these three points.

First, treating schooling attainment as behaviourally-determined within a dynamic life cycle affects substantially some of the estimates of the impact of increasing schooling on the outcomes being considered. For females: the negative impacts are much greater than in the usual estimates that do not control for the behavioral determinants of schooling on the probability of ever having been in an union, whether their first union or their first parenting was when they were younger than $18 \mathrm{y}$ and on their partner's BMI -- and the positive impacts on age of first union, age of first parenting and partner's and partner's parents' schooling attainment, likewise, are if anything greater. Such patterns suggest that, for example, there are unobserved factors (e.g. preferences for independence) that directly reduce the probability of being in a union and that are positively correlated with schooling attainment, so that when these factors are ignored in the estimates of the impact of schooling on being in a union ever or when young or having a first child when young, the estimated impact of schooling attainment is greater algebraically (i.e., less negative) than if there is control for these factors. For males: the apparently significantly negative associations of own schooling 
attainment with whether young at initiation of first union or at first parenting and the positive associations with age of first union and with partner's height do not appear significantly nonzero when males schooling attainment is treated as behaviorally-determined. Therefore for males there apparently are unobserved factors (e.g., innate ability, motivation) that are positive associated with schooling attainment and that directly affect some union outcomes so that they lead to misleading overestimates of some schooling impacts of schooling if they are not controlled (though, as for females, not controlling for the behavioral determination of schooling if anything leads to an underestimate of the impact on partner's and partner's parents' schooling attainment). Thus, in summary, if the preferred estimates are the IV estimates, then considering associations without control for the behavioral determination of schooling tends to lead to underestimates of the positive schooling impacts for females but for a number of outcomes leads to overestimates of the positive schooling impacts for males.

Second, a priori schooling would seem likely to be only one important factor in union-formation and initial parenting decisions. Other aspects of individuals' human capital (e.g., health, physical attractiveness) and of their parents (e.g., social and economic status) are likely to be important determinants of these decisions. Our estimates provide a little, but only a little, evidence for this proposition. The point estimate for the impact of schooling attainment is changed a fair amount for two of the outcomes when height and/or family background is included in the specification - age of marriage for females and age gap with partner for males. These two cases are consistent with the possibility that the failure to include other determinants of union matches might lead to misleading understanding of the impacts of schooling attainment, even if for most of the outcomes that we consider we do not find large effects.

Third, most of the related literature has focused on age(s) of first union and/or first parenting as the outcomes of interest. But there are other outcomes that are determined particularly with the age of first union that are likely to shape substantially individuals' and their children's subsequent options and welfare. We examine the impacts on selected union partner and union partner family characteristics that are also determined simultaneously with age of first union. We find substantial significant impacts on partner's and partner's parents' schooling attainment and, to a lesser extent, on partner's anthropometrics (in particular, reduced partner BMI for increases in female schooling attainment). The failure to incorporate such outcomes into the analysis is likely to mean that studies on the impact of schooling on ages of first union and first parenting, even if they are not subject to the problems noted above, are likely to result in only a partial understanding of the implications of the processes under study. 
Figure 1. Tracking subjects in 1969-77 data as of 2002-4

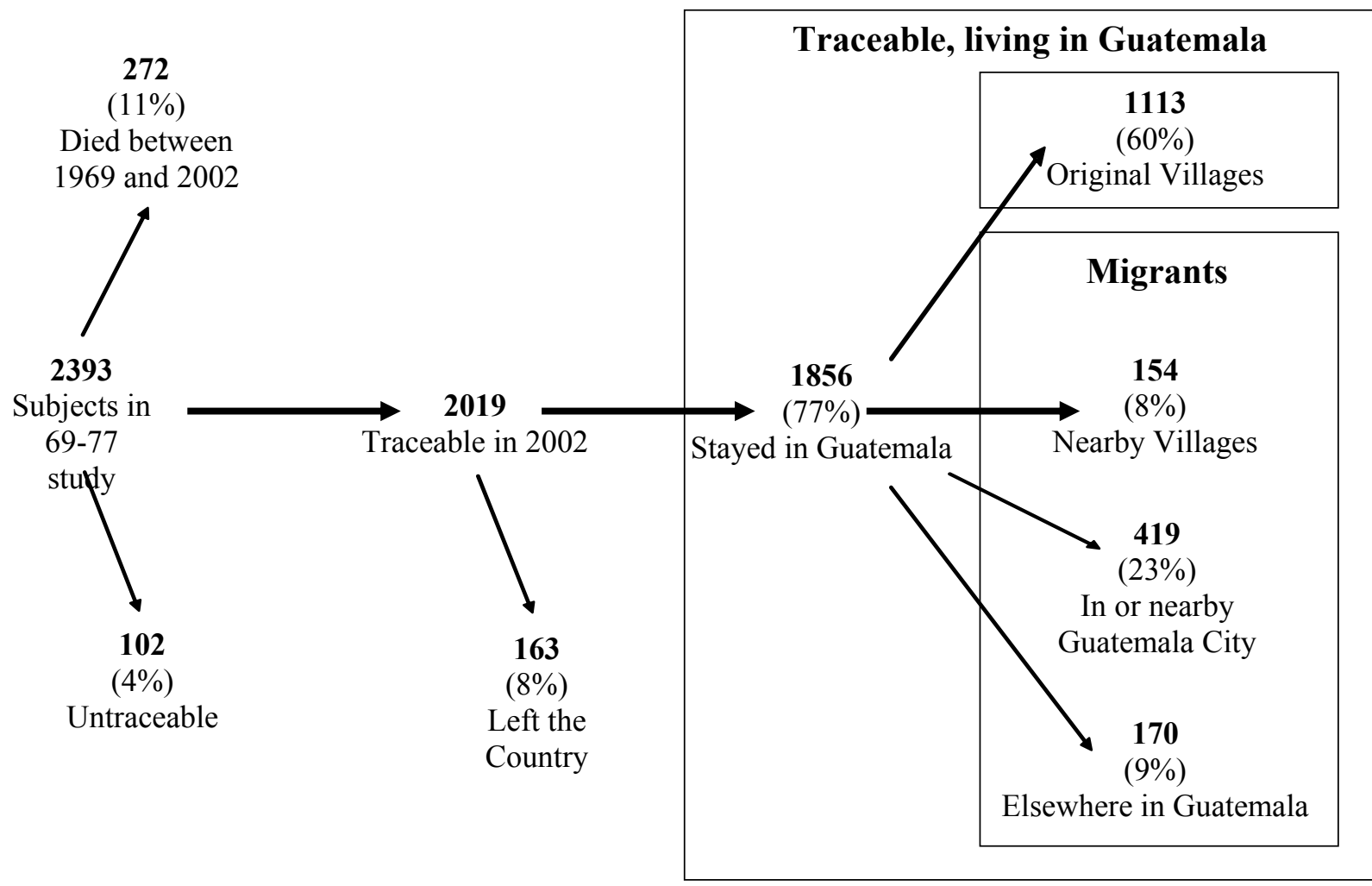


Table 1. Summary of union formation and first parenting outcomes and explanatory variables

\begin{tabular}{|c|c|c|c|c|c|c|}
\hline & \multicolumn{3}{|c|}{ Males } & \multicolumn{3}{|c|}{ Females } \\
\hline & $\begin{array}{c}\text { Mea } \\
\text { n }\end{array}$ & SD & $\mathbf{n}$ & Mean & SD & $\mathbf{n}$ \\
\hline \multicolumn{7}{|c|}{ Union Formation and First Parenting Outcomes $(\mathrm{Y})$} \\
\hline \multicolumn{7}{|c|}{ 1) Ever in a union and whether young (under 18y) at initiation of first union and first parenting: } \\
\hline Ever in union & 0.833 & 0.373 & 636 & 0.882 & 0.323 & 770 \\
\hline Whether young first union & 0.065 & 0.246 & 636 & 0.284 & 0.451 & 770 \\
\hline Whether young first parenting & 0.036 & 0.185 & 647 & 0.217 & 0.412 & 779 \\
\hline \multicolumn{7}{|l|}{ 2) Age at first union and first parenting: } \\
\hline Age at first union & 22.1 & 3.8 & 530 & 19.8 & 4.0 & 679 \\
\hline Age at first parenting & 23.2 & 3.9 & 523 & 20.3 & 3.8 & 692 \\
\hline Gap between first union \& parenting & 1.3 & 2.4 & 469 & 0.6 & 2.2 & 641 \\
\hline \multicolumn{7}{|c|}{ 3) Age gap with partner and partner characteristics: } \\
\hline Age gap (own age-partner's age) & 2.8 & 4.6 & 495 & -3.0 & 5.8 & 596 \\
\hline Partner's schooling attainment & 4.5 & 3.2 & 608 & 4.9 & 3.6 & 444 \\
\hline Partner's assets at union & 4342 & 17720 & 608 & 22111 & 44972 & 415 \\
\hline Height of partner & 150.5 & 5.2 & 532 & 162.5 & 5.7 & 403 \\
\hline BMI of partner & 26.6 & 4.6 & 528 & 25.5 & 3.7 & 399 \\
\hline \multicolumn{7}{|c|}{ 4) Partner's parental family (“in-laws") characteristics: } \\
\hline Land of inlaws (manzanas) & 5.0 & 70.3 & 487 & 2.8 & 9.5 & 404 \\
\hline Schooling mother-in-law & 1.6 & 2.2 & 573 & 1.7 & 2.2 & 541 \\
\hline Schooling father-in-law & 2.1 & 2.4 & 519 & 2.2 & 2.8 & 516 \\
\hline \multicolumn{7}{|l|}{ Explanatory Variables } \\
\hline \multicolumn{7}{|c|}{ 1) Early Adolescent Life-Cycle Stage Capital Stocks (Ka): } \\
\hline Schooling attainment & 5.3 & 3.3 & 638 & 4.5 & 3.1 & 725 \\
\hline Height & 162.8 & 5.9 & 592 & 150.5 & 5.5 & 669 \\
\hline \multicolumn{7}{|c|}{ 2) Family Background in Early-Adolescent Lifecycle Stage (Fa): } \\
\hline & & & 110 & & & 107 \\
\hline Mother's schooling & 1.4 & 1.7 & 1 & 1.3 & 1.6 & 4 \\
\hline & & & 104 & & & 101 \\
\hline Father's schooling & 1.8 & 2.2 & $\begin{array}{c}3 \\
107\end{array}$ & 1.7 & 2.1 & $\begin{array}{c}9 \\
101\end{array}$ \\
\hline Household wealth index in 1975 & -0.12 & 1.7 & $\begin{array}{c}101 \\
6\end{array}$ & -0.13 & 1.8 & $\begin{array}{c}101 \\
1\end{array}$ \\
\hline
\end{tabular}


Table 2. Determinants of the probability of ever having been in a union, having a first union or first child before age 18 for full sample of ever-married/united respondents

\begin{tabular}{|c|c|c|c|c|c|c|}
\hline \multirow[b]{2}{*}{ Outcomes } & \multicolumn{2}{|c|}{ Ever in union } & \multicolumn{2}{|c|}{ Young first union } & \multicolumn{2}{|c|}{ Young first parenting } \\
\hline & $\begin{array}{l}\text { Males } \\
\text { Coeff }\end{array}$ & $\begin{array}{l}\text { Females } \\
\text { Coeff }\end{array}$ & $\begin{array}{l}\text { Males } \\
\text { Coeff }\end{array}$ & $\begin{array}{l}\text { Females } \\
\text { Coeff }\end{array}$ & $\begin{array}{l}\text { Males } \\
\text { Coeff }\end{array}$ & $\begin{array}{l}\text { Females } \\
\text { Coeff }\end{array}$ \\
\hline \multicolumn{7}{|l|}{ (1) Schooling only (probit) } \\
\hline Schooling & -0.015 & -0.032 & -0.044 & -0.137 & -0.051 & -0.122 \\
\hline z & -0.74 & -1.49 & -2.01 & -7.89 & -1.48 & -6.76 \\
\hline Wald Chi-2 & 0.55 & 2.22 & 4.05 & 62.26 & 2.2 & 45.73 \\
\hline$p$-value & 0.46 & 0.14 & 0.04 & 0.00 & 0.14 & 0.00 \\
\hline$n$ & 572 & 697 & 572 & 697 & 567 & 704 \\
\hline \multicolumn{7}{|l|}{$\begin{array}{l}\text { (2) Schooling only (IV } \\
\text { probit) }\end{array}$} \\
\hline Schooling & -0.110 & -0.196 & -0.123 & -0.217 & 0.061 & -0.189 \\
\hline z & -1.38 & -2.59 & -1.41 & -2.77 & 0.55 & -2.06 \\
\hline Wald test of exogeneity & 1.32 & 3.26 & 0.75 & 0.89 & 0.98 & 0.48 \\
\hline$p$-value & 0.25 & 0.07 & 0.39 & 0.34 & 0.32 & 0.49 \\
\hline Wald Chi-2 & 1.91 & 6.73 & 1.99 & 7.68 & 0.31 & 4.24 \\
\hline p-value & 0.17 & 0.01 & 0.16 & 0.01 & 0.58 & 0.04 \\
\hline $\mathrm{n}$ & 572 & 697 & 572 & 697 & 567 & 704 \\
\hline \multicolumn{7}{|c|}{ (3) Schooling and height (IV probit) } \\
\hline Schooling & -0.085 & -0.197 & n.e.-1 & -0.226 & n.e.-1 & -0.191 \\
\hline z & -1.21 & -2.10 & & -3.12 & & -2.60 \\
\hline Height & -0.068 & 0.010 & & 0.047 & & 0.035 \\
\hline$z$ & -1.13 & 0.14 & & 0.76 & & 0.56 \\
\hline Wald test of exogeneity & 2.64 & 4.75 & & 6.27 & & 4.96 \\
\hline$p$-value & 0.27 & 0.09 & & 0.04 & & 0.08 \\
\hline Wald Chi-2 & 2.42 & 6.07 & & 15.12 & & 10.38 \\
\hline$p$-value & 0.30 & 0.05 & & 0.00 & & 0.01 \\
\hline$n$ & 422 & 538 & & 538 & & 535 \\
\hline \multicolumn{7}{|c|}{ (4) Schooling and height (IV) and family background } \\
\hline Schooling & -0.118 & n.e.-2 & n.e.-1 & -0.219 & n.e.-1 & 0.164 \\
\hline $\mathrm{z}$ & -1.53 & & & -2.96 & & -2.15 \\
\hline Height & -0.067 & & & 0.045 & & 0.034 \\
\hline z & -1.05 & & & 0.73 & & 0.56 \\
\hline Wald test of exogeneity & 2.93 & & & 4.46 & & 2.88 \\
\hline $\mathrm{p}$-value & 0.23 & & & 0.11 & & 0.24 \\
\hline Wald Chi-2 & 5.97 & & & 20.79 & & 16.98 \\
\hline$p$-value & $\underline{0.43}$ & & & 0.00 & & 0.01 \\
\hline $\mathrm{n}$ & $\overline{422}$ & & & 538 & & 535 \\
\hline
\end{tabular}

n.e.-1 Not estimated due to conformability error

n.e.-2 Not estimated because inverse matrix has missing values

$z$ values in bold are significantly nonzero at 0.05 level 
Table 3. Impact of schooling attainment on age at marriage and age at first parenting

(Censored regression with bootstrapped standard errors, with 1000 replications)

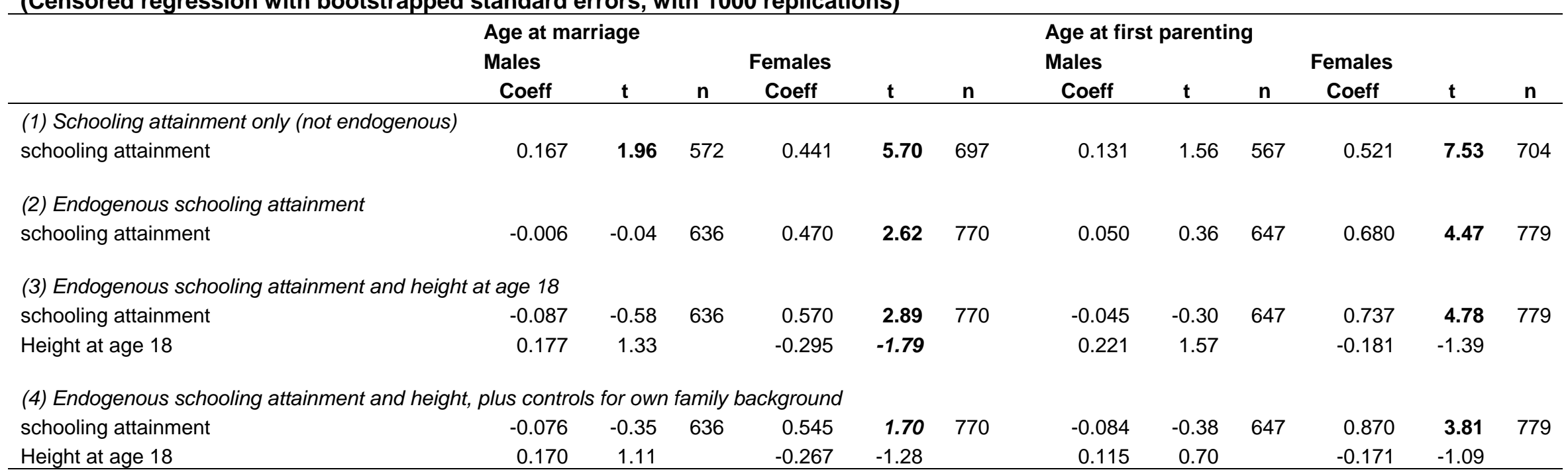

t-statistics in bold are significant at 0.05 level except those that also are in italics that are significant at 0.10 level. 
Table 4. Impact of schooling attainment on spouse/partner characteristics

Sample consists of individuals whose current union is their first union (88\%)

\begin{tabular}{|c|c|c|c|c|c|c|c|c|c|c|}
\hline \multirow[b]{2}{*}{ Outcomes } & \multicolumn{2}{|c|}{$\begin{array}{l}\text { Age gap } \\
\text { (own - partner } \\
\text { age) }\end{array}$} & \multicolumn{2}{|c|}{$\begin{array}{l}\text { Partner's } \\
\text { schooling } \\
\end{array}$} & \multicolumn{2}{|c|}{$\begin{array}{l}\text { Partner's } \\
\text { assets at union }\end{array}$} & \multicolumn{2}{|c|}{ Height of partner } & \multicolumn{2}{|c|}{ BMI of partner } \\
\hline & Males & Females & Males & Females & Males & Females & Males & Females & Males & Females \\
\hline \multicolumn{11}{|c|}{ (1) Schooling only (OLS) } \\
\hline Schooling & -0.071 & 0.113 & 0.507 & 0.612 & 499.518 & 1395.827 & 0.173 & 0.280 & -0.062 & 0.016 \\
\hline $\mathrm{t}$ & -1.03 & 1.25 & 10.47 & 8.68 & 1.52 & 1.49 & 1.99 & 2.38 & -0.91 & 0.21 \\
\hline $\mathrm{F}$ & 1.07 & 1.56 & 109.60 & 75.39 & 2.31 & 2.21 & 3.96 & 5.67 & 0.83 & 0.05 \\
\hline $\mathrm{p}$-value & 0.30 & 0.21 & 0.00 & 0.00 & 0.13 & 0.14 & 0.05 & 0.02 & 0.36 & 0.83 \\
\hline $\mathrm{n}$ & 401 & 479 & 396 & 350 & 399 & 327 & 349 & 317 & 345 & 313 \\
\hline \multicolumn{11}{|c|}{ (2) Schooling (IV) } \\
\hline Schooling & -0.392 & 0.134 & 0.585 & 0.833 & 70.288 & 2105.613 & -0.133 & -0.833 & -0.250 & -0.448 \\
\hline z & -1.97 & 0.43 & 4.54 & 4.77 & 0.14 & 0.74 & -0.58 & -2.33 & -1.13 & -2.11 \\
\hline Over-id & 16.34 & 12.45 & 14.68 & 25.75 & 13.20 & 20.69 & 20.34 & 13.11 & 26.9 & 20.01 \\
\hline$p$-value & 0.57 & 0.82 & 0.68 & 0.11 & 0.78 & 0.30 & 0.31 & 0.79 & 0.08 & 0.33 \\
\hline $\mathrm{F}$ & 3.85 & 0.18 & 20.49 & 22.63 & 0.02 & 0.54 & 0.33 & 5.38 & 1.27 & 4.44 \\
\hline$p$-value & 0.05 & 0.67 & 0.00 & 0.00 & 0.89 & 0.46 & 0.56 & 0.02 & 0.26 & 0.04 \\
\hline $\mathrm{n}$ & 401 & 479 & 396 & 350 & 399 & 327 & 349 & 317 & 345 & 313 \\
\hline \multicolumn{11}{|c|}{ (3) Schooling and height (IV) } \\
\hline Schooling & -0.313 & 0.169 & 0.630 & 0.730 & 912.440 & 3028.543 & -0.085 & -0.345 & 0.091 & -0.455 \\
\hline z & -1.27 & 0.55 & 4.40 & 4.27 & 1.16 & 1.04 & -0.34 & -1.17 & 0.33 & -2.02 \\
\hline Height & -0.432 & 0.169 & 0.045 & -0.069 & 407.410 & -616.239 & 0.293 & 0.269 & 0.412 & -0.133 \\
\hline z & -1.95 & 0.72 & 0.35 & -0.41 & 0.59 & -0.34 & 1.36 & 0.87 & 1.64 & -0.64 \\
\hline Over-id & 14.39 & 12.68 & 20.66 & 38.57 & 14.17 & 24.06 & 23.52 & 25.37 & 21.61 & 9.45 \\
\hline$p$-value & 0.64 & 0.76 & 0.24 & 0.00 & 0.66 & 0.12 & 0.13 & 0.09 & 0.20 & 0.93 \\
\hline $\mathrm{F}$ & 2.30 & 0.41 & 9.63 & 9.71 & 1.21 & 0.67 & 0.97 & 1.47 & 1.34 & 2.03 \\
\hline$p$-value & 0.10 & 0.67 & 0.00 & 0.00 & 0.30 & 0.51 & 0.38 & 0.23 & 0.26 & 0.13 \\
\hline $\mathrm{n}$ & 302 & 374 & 298 & 269 & 301 & 251 & 260 & 243 & 258 & 239 \\
\hline \multicolumn{11}{|c|}{ (4) Schooling and height (IV) and family background } \\
\hline Schooling & -0.264 & 0.069 & 0.643 & 0.740 & 922.406 & 2831.334 & -0.065 & -0.388 & -0.064 & -0.529 \\
\hline z & -0.97 & 0.22 & 4.43 & 4.22 & 0.73 & 0.89 & -0.25 & -1.21 & -0.24 & -2.20 \\
\hline Height & -0.551 & 0.021 & 0.030 & -0.009 & 40.341 & -1890.197 & 0.378 & 0.167 & 0.212 & -0.190 \\
\hline z & -2.49 & 0.09 & 0.22 & -0.05 & 0.05 & -1.16 & 1.74 & 0.52 & 0.95 & -0.91 \\
\hline Over-id & 13.20 & 16.48 & 20.77 & 35.18 & 13.64 & 18.56 & 22.18 & 26.29 & 25.77 & 7.74 \\
\hline$p$-value & 0.72 & 0.49 & 0.24 & 0.01 & 0.69 & 0.35 & 0.18 & 0.07 & 0.08 & 0.97 \\
\hline $\mathrm{F}$ & 1.79 & 0.83 & 9.88 & 6.14 & 0.82 & 3.86 & 0.77 & 0.77 & 0.96 & 1.49 \\
\hline$p$-value & 0.10 & 0.55 & 0.00 & 0.00 & 0.56 & 0.00 & 0.59 & 0.59 & 0.45 & 0.18 \\
\hline $\mathrm{n}$ & 302 & 374 & 298 & 269 & 301 & 251 & 260 & 243 & 258 & 239 \\
\hline
\end{tabular}

t- and z-statistics in bold are significant at 0.05 level except those that also are in italics that are significant at 0.10 level. 
Table 5. Impact of schooling on partner's family background characteristics (sample consists of individuals whose current union is their first union -- 88\%)

\begin{tabular}{|c|c|c|c|c|c|c|}
\hline \multirow[b]{3}{*}{ Outcomes } & \multirow{2}{*}{\multicolumn{2}{|c|}{ Inlaw land holdings }} & \multicolumn{4}{|c|}{ Inlaw schooling attainment } \\
\hline & & & \multicolumn{2}{|c|}{ Mother-in-law } & \multicolumn{2}{|c|}{ Father-in-law } \\
\hline & Males & Females & Males & Females & Males & Females \\
\hline \multicolumn{7}{|c|}{ (1) Schooling only (OLS) } \\
\hline Schooling & -0.163 & 0.531 & 0.131 & 0.218 & 0.178 & 0.335 \\
\hline $\mathrm{t}$ & -0.81 & 1.33 & 3.66 & 4.23 & 4.43 & 5.37 \\
\hline $\mathrm{F}$ & 0.66 & 1.76 & 13.40 & 17.89 & 19.59 & 28.86 \\
\hline$p$-value & 0.42 & 0.19 & 0.00 & 0.00 & 0.00 & 0.00 \\
\hline $\mathrm{n}$ & 399 & 324 & 379 & 427 & 347 & 412 \\
\hline \multicolumn{7}{|c|}{ (2) Schooling (IV) } \\
\hline Schooling & -1.851 & -0.405 & 0.217 & 0.338 & 0.381 & 0.845 \\
\hline z & -1.44 & -1.10 & 2.34 & 2.79 & 3.32 & 4.96 \\
\hline Over-id & 6.60 & 15.61 & 22.09 & 17.33 & 17.40 & 16.34 \\
\hline p-value & 0.99 & 0.62 & 0.23 & 0.50 & 0.50 & 0.57 \\
\hline $\mathrm{F}$ & 2.05 & 1.20 & 5.43 & 7.73 & 10.93 & 24.44 \\
\hline$p$-value & 0.15 & 0.27 & 0.02 & 0.01 & 0.00 & 0.00 \\
\hline $\mathrm{n}$ & 399 & 324 & 379 & 427 & 347 & 412 \\
\hline \multicolumn{7}{|c|}{ (3) Schooling and height (IV) } \\
\hline Schooling & -0.256 & 0.247 & 0.260 & 0.286 & 0.418 & 0.729 \\
\hline z & -1.45 & 1.11 & 2.35 & 2.31 & 3.43 & 4.27 \\
\hline Height & 0.009 & 0.255 & -0.094 & -0.023 & -0.070 & 0.114 \\
\hline$z$ & 0.06 & 0.73 & -1.20 & -0.23 & -0.64 & 0.74 \\
\hline Over-id & 22.48 & 18.32 & 19.38 & 18.24 & 16.12 & 17.09 \\
\hline$p$-value & 0.17 & 0.37 & 0.31 & 0.37 & 0.52 & 0.45 \\
\hline $\mathrm{F}$ & 1.73 & 0.69 & 3.04 & 3.13 & 5.92 & 9.06 \\
\hline$p$-value & 0.18 & 0.51 & 0.05 & 0.05 & 0.00 & 0.00 \\
\hline$n$ & 301 & 248 & 291 & 333 & 266 & 319 \\
\hline \multicolumn{7}{|c|}{ (4) Schooling and health (IV) and family background } \\
\hline Schooling & -0.301 & -0.094 & 0.287 & 0.343 & 0.352 & 0.736 \\
\hline z & -1.99 & -0.26 & 2.44 & 2.75 & 2.71 & 4.36 \\
\hline Height & -0.062 & 0.159 & -0.082 & -0.019 & -0.069 & 0.132 \\
\hline z & -0.410 & 0.41 & -1.04 & -0.19 & -0.59 & 0.83 \\
\hline Over-id & 16.22 & 10.75 & 19.18 & 17.07 & 17.03 & 17.14 \\
\hline$p$-value & 0.51 & 0.87 & 0.32 & 0.45 & 0.45 & 0.44 \\
\hline $\mathrm{F}$ & 0.81 & 5.17 & 1.64 & 1.93 & 3.22 & 3.43 \\
\hline$p$-value & 0.57 & 0.00 & 0.14 & 0.08 & 0.00 & 0.00 \\
\hline$n$ & 301 & 248 & 291 & 333 & 266 & 319 \\
\hline
\end{tabular}

t- and z-statistics in bold are significant at 0.05 level. 


\begin{tabular}{|c|c|c|}
\hline \multicolumn{3}{|c|}{$\begin{array}{l}\text { Appendix table } A \text {. } \\
\text { Impact of schooling } \\
\text { on age } \\
\text { gap between first parenting and first union }\end{array}$} \\
\hline & \multicolumn{2}{|c|}{$\begin{array}{l}\text { Age Gap between } \\
\text { first } \\
\text { union \& parenting }\end{array}$} \\
\hline & Males & Females \\
\hline \multicolumn{3}{|c|}{ (1) Schooling only (OLS) } \\
\hline Schooling & -0.027 & 0.008 \\
\hline $\mathrm{t}$ & -0.97 & 0.28 \\
\hline $\mathrm{F}$ & 0.95 & 0.08 \\
\hline p-value & 0.33 & 0.78 \\
\hline $\mathrm{n}$ & 427 & 584 \\
\hline \multicolumn{3}{|c|}{ (2) Schooling (IV) } \\
\hline Schooling & -0.144 & 0.122 \\
\hline$z$ & -1.55 & 1.03 \\
\hline Over-id & 7.62 & 9.06 \\
\hline$p$-value & 0.91 & 0.83 \\
\hline $\mathrm{F}$ & 2.39 & 1.06 \\
\hline p-value & 0.12 & 0.30 \\
\hline n & 427 & 584 \\
\hline \multicolumn{3}{|c|}{ (3) Schooling and height (IV) } \\
\hline Schooling & -0.077 & 0.216 \\
\hline z & -0.68 & 1.56 \\
\hline Height & -0.018 & 0.108 \\
\hline z & -0.25 & 0.93 \\
\hline Over-id & 13.15 & 10.84 \\
\hline p-value & 0.73 & 0.86 \\
\hline $\mathrm{F}$ & 0.27 & 1.71 \\
\hline$p$-value & 0.76 & 0.18 \\
\hline$n$ & 311 & 449 \\
\hline \multicolumn{3}{|c|}{ (4) Schooling and height (IV) and family background } \\
\hline Schooling & -0.078 & 0.185 \\
\hline z & -0.70 & 1.25 \\
\hline Height & -0.054 & 0.039 \\
\hline z & -0.75 & 0.36 \\
\hline Over-id & 13.91 & 12.14 \\
\hline$p$-value & 0.67 & 0.79 \\
\hline $\mathrm{F}$ & 0.61 & 1.36 \\
\hline p-value & 0.73 & 0.23 \\
\hline $\mathrm{n}$ & 311 & 449 \\
\hline
\end{tabular}




\section{References}

Becker, Gary S., 1991, A Treatise on the Family, Cambridge, MA: Harvard University Press, second edition.

Behrman, Jere R., John Hoddinott, John A. Maluccio, Erica Soler-Hampejsek, Emily L. Behrman, Reynaldo Martorell, Manuel Ramirez and Aryeh D. Stein, 2005,"What Determines Adult Skills? Impacts of Pre-School, School-Years and Post-School Experiences in Guatemala”, Philadelphia, PA: University of Pennsylvania, mimeo.

Behrman, Jere R. and Mark R. Rosenzweig, 1999, "Ability' Biases in Schooling Returns and Twins: A Test and New Estimates," Economics of Education Review 18, 159-167.

Behrman, Jere R. and Mark R. Rosenzweig, 2002, "Does Increasing Women's Schooling Raise the Schooling of the Next Generation?" American Economic Review 92:1, 323-334.

Behrman, Jere R. and Mark R. Rosenzweig, 2004, "Returns to Birthweight," Review of Economics and Statistics 86:2 (May), 586-601.

Behrman, Jere R. and Mark R. Rosenzweig, 2005, "Does Increasing Women's Schooling Raise the Schooling of the Next Generation? - Reply” American Economic Review 95 (December).

Behrman, Jere R., Mark R. Rosenzweig and Paul Taubman, 1994, "Endowments and the Allocation of Schooling in the Family and in the Marriage Market: The Twins Experiment," Journal of Political Economy 102:6 (December), 1131-1174.

Behrman, Jere R., Mark R. Rosenzweig and Paul Taubman, 1996, "College Choice and Wages: Estimates Using Data on Female Twins," Review of Economics and Statistics 73:4 (November), 672-685.

Bergeron, Gilles, 1992. "Social and Economic Development in Four Latino Communities of Eastern Guatemala: A Comparative Description," Food and Nutrition Bulletin, 14:3, 221-236

Bertrand, Marianne, Esther Duflo and Sendhil Mullainathan, 2004, "How Much Should We Trust Differences-in-Differences Estimates?" Quarterly Journal of Economics 119:1 (February), 249-275.

Boulier, Bryan L. and Mark R. Rosenzweig, 1984, "Schooling, Search and Spouse Selection: Testing Economic Theories of Marriage and Household Behavior," Journal of Political Economy 92:4 (August), 712-732.

Estudio 1360. 2002. Changes in the Socioeconomic and Cultural Conditions that Affect the Formation of Human Capital and Economic Productivity. Final report presented to INCAP, 13 May 2002.

Grajeda, Rubén, Jere R. Behrman, Rafael Flores, John A. Maluccio, Reynaldo Martorell and Aryeh D. Stein, 2005, "The Human Capital Study 2002-04: Tracking, Data Collection, Coverage, and Attrition," Food and Nutrition Bulletin 26:2 (Supplement 1), S15-S24.

Habicht, Jean-Pierre and Reynaldo Martorell, 1992, "Objectives, Research Design, and Implementation of the INCAP Longitudinal Study" Food and Nutrition Bulletin 14:3, 176190.

Hoddinott, John, Jere R. Behrman and Reynaldo Martorell, 2005, "Labor force Activities and Income Among Young Guatemalan Adults," Food and Nutrition Bulletin 26:2 (Supplement 1), S98-S109.

Huber, Peter, 1967, “The Behavior of Maximum Likelihood Estimates under Non-Standard Conditions," Proceedings of the Fifth Berkeley Symposium in Mathematical Statistics and Probability 1, 221-233.

Maluccio, John A., John Hoddinott, Jere R. Behrman, Agnes Quisumbing, Reynaldo Martorell and Aryeh D. Stein, 2005a, "The Impact of an Experimental Nutritional Intervention on Education into Adulthood in Rural Guatemala," Philadelphia-Washington-Atlanta: University of Pennsylvania, IFPRI, Emory, processed. 
Maluccio, John A., Paúl Melgar, Humberto Méndez, Alexis Murphy and Kathryn M. Yount, 2005b, "Social and Economic Development and Change in Four Guatemalan villages: Demographics, Schooling, Occupation, and Assets." Food and Nutrition Bulletin 26:2 (Supplement 1), S25-S45.

Maluccio, John A., Alexis Murphy and Kathryn M. Yount, 2005, "Research note: a Socioeconomic Index for the INCAP Longitudinal Study 1969-77," Food and Nutrition Bulletin 26:2 (Supplement 1), S120-S124.

Mare, Robert D., 1991, "Five Decades of Educational Assortative Mating." American Sociological Review 56: 15-32.

Martorell, Reynaldo, Jere R. Behrman, Rafael Flores, and Aryeh D. Stein, 2005, "Rationale for a Follow-up Focusing on Economic Productivity," Food and Nutrition Bulletin 26:2 (Supplement 1), S5-S14.

Martorell Reynaldo, Jean-Pierre Habicht and Juan A. Rivera, 1995, "History and design of the INCAP Longitudinal Study (1969-77) and its Follow up (1988-89)," Journal of Nutrition, 125:4S, 1027S-1041S.

Martorell, Reynaldo, Usha Ramakrishnan, Dirk G. Schroeder, Paúl Melgar and Lynette Neufeld, 1998, "Intrauterine Growth Retardation, Body size, Body Composition and Physical Performance in Adolescence," European Journal of Clinical Nutrition 52:S1, S43-S53.

National Research Council and Institute of Medicine (NRC/IOM), panel on Transitions to Adulthood in Developing Countries, Cynthia B. Lloyd (ed.). 2005. Growing Up Global: The Changing Transitions to Adulthood in Developing Countries, Washington, DC: National Academies Press.

Pivaral, V.M., 1972, Características Económicas y Socioculturales de Cuatro Aldeas Ladinas de Guatemala, Ministerio de Educación Pública, Instituto Indigenista Nacional, Guatemala.

Psacharopoulos, George and Harry Patrinos, 2004, "Returns to Investment in Education: A Further Update," Education Economics 12:2, 111-134.

Quisumbing, Agnes R., Jere R. Behrman, John A. Maluccio' Alexis Murphy, and Kathryn M. Yount, 2005, "Levels, Correlates and Differences in Human, Physical, and Financial Assets Brought Into Marriages by Young Guatemalan Adults," Food and Nutrition Bulletin 26:2 (Supplement 1), S55-S67.

Quisumbing, Agnes R. and John A. Maluccio, 2003, "Resources at Marriage and Intrahousehold Allocation: Evidence from Bangladesh, Ethiopia, Indonesia, and South Africa," Oxford Bulletin of Economics and Statistics 65 (3): 283-328.

Quisumbing, Agnes R. and Kelly Hallman, 2005, "Marriage in Transition: Evidence on Age, Education, and Assets from Six Developing Countries," in Lloyd, Cynthia B., Jere R. Behrman, Nelly P. Stromquist, and Barney Cohen, Editors, The Changing Transitions to Adulthood in Developing Countries: Selected Studies, Panel on Transitions to Adulthood in Developing Countries, Committee on Population, Division of Behavioral and Social Sciences and Education, Washington, DC: National Academies Press.

Ramakrishnan, Usha, Kathryn Yount, Jere R. Behrman, Misa Graff, Ruben Grajeda Toledo, and Aryeh D. Stein, 2005, "Fertility Patterns and Reproductive Outcomes among Young Guatemalan Adults,"Food and Nutrition Bulletin 26:2 (Supplement 1), S68

Read, Merrill .S. and Jean-Pierre Habicht, 1992, "History of the INCAP Longitudinal Study on the Effects of Early Nutrition Supplementation in Child Growth and Development," Food and Nutrition Bulletin 14:3, 169-175.

Schroeder, Dirk G., Haley J. Kaplowitz and Reynaldo Martorell, 1992, "Patterns and Predictors of Participation and Consumption of Supplement in an Intervention Study in Rural Guatemala," Food and Nutrition Bulletin 14:3, 191-200. 
Stein Aryeh D., Jere Behrman, Ann DiGirolamo, Ruben Grajeda Reynaldo Martorell, Agnes Quisumbing, and Usha Ramakrishnan, 2005, "Schooling, Educational Achievement and Cognitive Functioning Among Young Guatemalan Adults," Food and Nutrition Bulletin 26:2 (Supplement 1), S46-S54.

White, Hal, 1980, "A Heteroscedasticity-Consistent Covariance Matrix and a Direct Test for Heteroscedasticity," Econometrica 48:4, 817-838. 
